\title{
Leh Laweng: Reinventing "Lakhon Phanthang" Hybrid Dance Theatre in a Post-Traditional Style
}

\author{
Phakamas Jirajarupat (ผกามาศ จิรจารุภัทร) \\ Department of Thai Dramatic Arts, Faculty of Fine and Applied Arts, \\ Suan Sunandha Rajabhat University, Bangkok, Thailand \\ phakamas.ji@ssru.ac.th
}

Nataporn Rattanachaiwong (ณฐภรณ์ รัตนชัยวงศ์) Department of Performing Arts, Faculty of Fine and Applied Arts, Suan Sunandha Rajabhat University, Bangkok, Thailand nataporn.ra@ssru.ac.th

\begin{abstract}
Leh Laweng (The Wiles of Laweng) was a new dance-drama the authors created in 2019 in a post-traditional style of "Lakhon Phanthang" or hybrid dance theatre form. Working in our faculty's theatre, the authors developed an original woman-centerd plot from the well-known Thai epic poem The Story of Phra Aphai Mani by Sunthorn Phu. Our new four-act script focused on the key, but neglected, figure Laweng - a Westernstyled warrior queen - and reworked traditional modes of presentation to better convey a new sensibility for today's audiences. While performed by traditional performers, cast for their abilities in traditional dancing and their knowledge, without regard to their gender, their acting also incorporated some modern theatrical techniques. The new style of this hybrid Thai dance play sought to convey a new message to contemporary audiences, while retaining key aspects of the Thai traditional form and taking on a more contemporary look. The process of reinventing Lakhon Phanthang into a posttraditional performance allowed artists, academics, and students to enrich their knowledge and through this new hybrid play for today's audiences.
\end{abstract}

\section{Keywords}

Lakhon Phanthang - performance research - post-traditional performance - Thai dance drama - Phra Aphai Mani - Sunthorn Phu - scriptwriting - directing 
บทคัดย่อ

“เล่ห์ละเวง" : การประดิษฐ์ซ้ำละครพันทางในรูปแบบหลังจารีตนิยม

“ล่ห์ละเวง” เป็นละครพันทางหรือละครลูกผสมที่ถูกประดิษฐ์สร้างขึ้นใหม่ในรูปแบบหลังจารีต นิยมเมื่อปี 2562 จัดแสดงที่คณะศิลปกรรมศาสตร์ มหาวิทยาลัยราชภัฏสวนสุนันทา ผู้วิจัยได้พัฒนา โครงเรื่องขึ้นโดยมุ่งเน้นการสร้างและปรับกระบวนทัศน์ในการให้ความสำคัญกับบทบาทและตัว ละครผู้หญิง จากวรรณคดีที่มีชื่อเสียงโด่งดังของไทยเรื่องพระอภัยมณีโดยสุนทรภู่ บทละคร 4 องก์ สะท้อนการตีความและการให้ความสำคัญต่อความรู้สึกนึกคิด บทบาทหน้าที่และแรงขับภายในใจ ของ “นางละเวง" ตัวละครหญิงชาวตะวันตกผู้เป็นนักรบและราชินีในวรรณคดียอดนิยม ซึ่งถือเป็นการสร้างมุมมองและสุนทรียรสใหม่ให้เกิดขึ้นแก่ผู้ชมในยุคปัจจุบัน ละครเรื่องนี้นำ เสนอโดยนักแสดงที่มีพื้นฐานด้านการแสดงแบบจารีตนิยมที่ผ่านการฝึกปฏิบัติการการแสดงด้วย กระบวนวิธีทางการละครสมัยใหม่ การคัดเลือกตัวละครพิจารณาจากทักษะและความสามารถแทน การคัดเลือกตัวละครตามเพศสภาพของผู้แสดง ละครลูกผสมรูปแบบใหม่นี้ค้นหาวิธีการนำสาร ใหม่ไปสู่ผู้ชมร่วมสมัยด้วยการรักษารูปแบบการแสดงตามจารีตแต่มีความร่วมสมัยมากขึ้น การประดิษฐ์ซ้ำละครพันทางในรูปแบบหลังจารีตนิยมเปิดโอกาสให้ศิลปิน นักวิชาการ และ นักศึกษา ได้มีโอกาสค้นหาคุณค่าและพัฒนาศักยภาพในตนเอง ผ่านละครลูกผสมแบบใหม่สำหรับ ผู้ชมในยุคปัจจุบัน

\section{Introduction ${ }^{1}$}

This paper analyzes the working process the authors used to create and stage a new Lakhon Phanthang play in a post-traditional style in 2019. "Lakhon Phanthang," literally "the theatre of a thousand styles" is a mixed multicultural dance-drama form that first emerged in Thailand during the $19^{\text {th }}$-century under royal patronage as a type of commercial theatre. It was formalized as a traditional dance genre in the 1940s by masters working in the new Thai Fine Arts Department, standardized and modernized there in the 1980s. It is still taught there today and in other official dance academies in Thailand. A unique feature of the form is how it represents non-Thai ethnic groups, such as

1 See the photos of this article at the URL https://doi.org/10.6084/mg.figshare.13247198.

2 This project was done as part of a three-year national umbrella project funded by the former Thailand Research Fund project (2016-2019) called "Performance Research: Doing Creative Research in Contemporary Thai Performing Arts" (RTA 5980010) run by Professor Pornrat Damrhung out of Chulalongkorn University in Bangkok. In 2019 the Thailand Research Fund was folded into the new Thailand Science Research and Innovation (TSRI). The authors would like to thank the two anonymous reviews of this paper for providing thoughtful comments on an earlier version of this paper. We have used their comments and suggestions as the basis to clarify some points and to provide better examples in the current version of the paper. 
Chinese, Burmese, Mons, Khaek (Muslims), or Westerners. The distinctive often stereotypical - representations of ethnic groups and cultures are seen in its eclectic costumes, stylized movements, mannerisms, language and ethnic stereotypes of these non-Thai "Others." The hybrid performance style likewise includes many Thai traditional dances to show a distinct way of being "Thai but not Thai" (Jirajarupat 2014a, 17). Lakhon Phanthang has been classified as a hybrid dance-drama which amalgamated Thai traditional dances and other performance genres over a century ago, incorporating diverse styles from a time of rapid socio-political and cultural change in Thailand.

The plots of most Lakhon Phanthang pieces center on characters of diverse ethnicities or from countries outside Thailand. For example, the famous piece "Pra Lor" develops a story connected to the Lao ethnic group, and the plot of Rajathiraj focuses on the Mon ethnic group tied to Burma. Lakhon Panthang's atmosphere, scenery, and costumes, and its singing style and music, also reflect ethnic and national diversity, coalescing from the time of King Rama $\mathrm{V}$ (r. 1868-1910) and evolving since then. Dr. Seree Wangnaitham (1937-2007) developed Lakhon Phanthang to a high level and provided it with a consistent style and look. Yet the gap between today's audiences and the older Lakhon Phanthang form, which uses traditional conventions, has widened in recent decades.

Polachan $(2020,223)$ observes that the aesthetics of Thai traditional dancedrama is shown more in its theatrical presentation than its story. Much of Thai traditional performance, like plot and characters, derives from Thai classic literature, so little explanation is needed. Audiences focus on the graceful moves or voices of specific performers in assessing the quality of the performance more than the storyline. Most Thai traditional theatre simply informs audiences of the characters' activities - bathing, dressing, and preparing for a battle - to clue them into the scenes being performed. Hinvimarn (2001) notes that appreciating Thai traditional theatre by today's audiences often depends more on their emotional connections to characters or performers and the onstage action than on the play's content per se. Plots typical of modern media formats are brief and flexible, so audiences are now more used to focusing on the contents more than on characters' emotions and movements. Since today's audiences often lose interest in Thai traditional theatre because of its slow pacing, the playwright sought to offer audiences a story that is more engaging. The specific ways of doing this will be discussed below.

This project uses other notions of modern cultural change, such as ideas of "invented tradition" by Hobsbawm and Ranger (1983) and "post-traditional society" of Eisenstadt (1973) and Giddens (1994). Matthew Cohen connects "posttraditional" ideas to artists in Southeast Asia, who work to free "local cultural 
forms from codified aesthetic frames imposed on them" so they can "address pressing issues facing local communities and the nation." (Cohen 2016a, 188). These ideas help us to frame our efforts to reinvent Lakhon Phanthang for today's audiences. "Post-traditional" work consists of practices of social value, belief, culture, custom, and other activities that arise once a traditional period has passed. Cohen sees this work as using "the aesthetic forms of inherited art forms," marking it out as "traditional," while often upending norms, mixing genres and "involves social reconfigurations of performance scenes," indicating a new take on these forms (Cohen 2016a, 188). Our project used "posttraditional" methods which modified aspects of traditional practice to suit the current socio-cultural context.

"Post-traditional" work underscores the continued power of traditional practices and cultural forms in today's society, despite increased modernization and global interconnection. These "post-traditional" forms can remind community members of traditional customs and origins while permitting them to step out of the work that first produced and sustained them. We explore ways of doing "post-traditional" work such as deconstructing, decoding and reworking "traditional" ways of thinking and norms still in contemporary society. "Post-traditional" forms do not mean abandoning traditional modes of presentation, but viewing those forms in a different light, and carefully selecting and modifying some elements of these forms to produce new perspective or feelings in today's society. This process has long been part of modernity, where, as Hobsbawm and Ranger have shown, traditions can be newly constructed to serve new or different political and social roles, through what they call the "reinvention of tradition." We aim to show one way to reinvent Lakhon Phanthang as a post-traditional form for $2 \mathrm{1}^{\text {st }}$ century artists and audiences in Bangkok.

This article consists of two main parts, followed by a conclusion. After first analyzing how Nataporn Rattanachaiwong wrote a contemporary script for the new Lakhon Phanthang play Leh Lawang by using a deconstructionist feminist approach to its tradition, Phakamas Jirajarupat examines how she re-created Leh Lawang for the stage, using the new script for a dance theatre production to reinterpret it for contemporary audiences. The conclusion considers the main findings of our working process and suggests some implications for future work.

\section{$2 \quad$ Reinventing Lakhon Phanthang for the $21^{\text {st }}$ Century}

The new Leh Laweng play is no less hybrid than those we who researched and created it. Our backgrounds, interests and focus are products of a complex 
blend of different forms of expertise and training. One of us (Phakamas) specializes in Thai traditional dance and was involved in directing, while the other (Nataporn) is a Western theatre specialist who creatively made the script. This makes the research project into an example of cross-disciplinary work in two theatrical styles that sought to create a hybrid play which mixed traditional forms and explored foreign influence on the frontiers of post-traditional theatre. We pursued three main goals in devising the script.

1. Write a new Lakhon Phanthang script based on familiar Thai literature but give it a new focus that uses some Western dramatic techniques.

2. Focus the new script on a main foreign character never featured in traditional Lakhon Phanthang.

3. Stage the new piece in a reworked setting with a familiar atmosphere of traditional Lakhon Phanthang drama.

The core story of this new play comes from the epic poem Phra Aphai Mani, which Sunthorn Phu (1786-1855) completed in 1844. It became a key source of traditional Lakhon Phanthang plays since the early 2oth century. Using this source, we focused on Nang Laweng, its strong Western female character, and made her the lead character in our play. Most Thai people know Laweng as the queen of the city of Longka, but some argue that she is modeled on the British Queen Victoria (Wongthes 2016). Her role in the 19th-century poem and in many plays derived from this poem is a female antagonist to the male hero Phra Aphai Mani. Unlike Suwanmali, the main wife of the hero, Laweng is often portrayed as Phra Aphai Mani's wicked mistress who uses her feminine charms to capture his attention and divert him from his main wife. Reading Laweng from a neutral perspective, however, shows her to be situationally forced to fight and behave as she does to survive in a male-dominated society. As someone brought up as delicate princess by King of Longka and her brother, she was eventually crowned Queen, and pushed to fight Phra Aphai Mani by her courtiers after the death of her father, the King of Longka, and then belatedly seems to fall in love with her one-time enemy, Phra Aphai Mani. The fighting scene between Phra Aphai Mani and Laweng is normally performed near the beginning of traditional Lakhon Phanthang performances, with Laweng finally falling in love with Phra Aphai Mani. Since our new script focuses on Laweng's motivations and goals that lead up to that fight, we end our version with her fight against Phra Aphai Mani, thus suggesting that the traditional romantic ending of the fight is actually part of Laweng's plans, too.

To write our script, we first studied the "Phra Aphai Mani" poem and many Lakhon Phanthang scripts. We discovered that Laweng appeared in five Lakhon 
Phanthang scripts, the oldest of which was written in $195^{2}$ in the Fine Arts Department. They included typical traditional Thai storytelling elements, such as: 1. A non-linear plot, arranged in a non-consecutive order, used since Thai traditional plays are usually based on familiar stories whose characters and plots are already known.

2. Many key characters whose roles and actions are situationally passive rather than active, which makes their motive and motivation less important.

3. An omnipresent point of view, with offstage singers narrating the feelings of the characters directly to audiences.

Our new Lakhon Phanthang play script reverses the order of things in most earlier scripts. We start from Laweng's motivations, which only culminate in her fight with Phra Aphai Mani at the end of our play. We developed her role and actions through a feminist and a deconstructive reading of the source poem that runs counter to most Lakhon Phanthang plays she appears in. By making her the main character, we needed to find more complex reasons and motives for her actions. We found this complexity in the role of the "Tra Rahu" or sacred amulet of the Longka throne in the story. Its role became key to our reading of Laweng's motivations and the plot we develop from them. The magical "Tra Rahu" could protect its bearer from all dangers. In the traditional poem, the "Tra Rahu" is first mentioned in a scene where Laweng decides to take the throne to replace her father, who had just died, along with her brother, in battle with Phra Aphai Mani. She decides to do this because she was persuaded by her trusted nobleman's argument that Laweng's father had died because he did not carry the "Tra Rahu" to battle. The nobleman argues that Laweng's father likely did not take the "Tra Rahu" with him since he wanted to leave it behind to protect his dearest daughter Laweng. But he could also have left it behind with Laweng due to a trick she had arranged to have her father leave it with her, since it would allow her to go into battle with Phra Aphai Mani. In this key scene, Laweng, dressed as a man, set fire around Pluek city, but Phra Aphai Mani played his magic flute which could make all those who heard it fall asleep. Yet the sound of the flute did not affect Laweng, since she was protected by the "Tra Rahu." Once the two met with no disguise, Phra Aphai Mani falls in love with Laweng at once, and plays a flirting song to make her fall in love with him, enrapturing Laweng with his music, now more powerful than the "Tra Rahu."

These incidents from the poem led us to ask two question about the role of the Tra Rahu in the story: 1. Why did the King of Longka leave behind his sacred amulet while he went to battle? 2. Why was Laweng lured by the flirting song played by Phra Aphai Mani when she carried Tra Rahu with her? Working from 
these questions, we reinterpreted the character of Laweng, partly using Gustav Freytag's five-part "plot pyramid," which modifies Aristotle's classic three-part plot structure, and used the "wiles" or "tricks" ("leh" in Thai) of Laweng to move the plot along in each act. This permitted audiences with little or no background knowledge of the literature to better understand Laweng's intentions and to follow her action with more interest.

With this new focus, our plot fell into four scenes which collectively seek to motivate Laweng's actions ending in her fight with Phra Aphai Mani. Scene 1 stresses how courtiers who announced the death of Laweng's father and brother convince Laweng to take the Longka throne, as well as showing Laweng's vow to take revenge on Phra Aphai Mani. We altered the plot of this act to suggest that Laweng tricked her father to leave the sacred Tra Rahu gem behind with her, hoping that her father would fail in battle so that she would be able to showcase her formidable fighting abilities against Phra Aphai Mani. In Scene 2, Laweng used her tricks and charm to attract princes from other countries to help her win in battle with Phra Aphai Mani, promising those who help her win her hand in marriage. In Scene 3, a dialogue between two of Laweng's maids show how the deaths of those princes in battle was due to their petty jealousy over how other princes would marry Laweng if they would win the battle, which led them to fight one other before the real battle with Phra Aphai Mani. This was written in a comedic style to add more humor, as is usual in Thai traditional plays which often use jokes to relax the audience. In Scene 4, Laweng, disguised as a man, meets Phra Aphai Mani on the battlefield. This act presents the best-known scene for Thai audiences familiar with traditional Lakhon Phanthang. But in our new play, we twisted the ending differently from standard versions, so that rather than having Laweng fall in love with Phra Aphai Mani because of his magical flute song, we have Laweng trick him into thinking she was lured by his song, when really she was not. Rather, it is because she knew Phra Aphai Mani's weakness was his being easily attracted by beautiful women, so he would do anything Laweng wants. Laweng uses this point of his easily falling in love to control him.

As suggested by the title of our new play, Leh Laweng meaning the "wiles" or the "cunning" of Laweng, who is full of "tricks." Our script shows Laweng using one key trick in each of the four scene, especially in the scene 4 plot twist.

Once the new plot had its main structure, we developed dialogues based on different types of Lakhon Phanthang's language: ordinary conversations, verses, songs and chorus. The songs and choruses sung by singers off-stage provided a more international atmosphere than normal from Laweng as the Western female lead. Her conversations and songs included some English words and 
phrases, especially in the last part of the play to reiterate Laweng's intention. The playwright sought to focus Leh Laweng on a neglected female and foreign character, reworking the plot or storyline of traditional Lakhon Phanthang, and altering storytelling techniques. Lakhon Phanthang, a form of Thai dancedrama, uses its script to permit performers to show their dance skills, rather than focus on the storyline. For younger audiences unfamiliar with the story of Phra Aphai Mani and the form of Lakhon Phanthang, Gustav Freytag's pyramid offers a model for structuring the plot where the main character is active, thus permitting the audience to follow the main character's journey with more interest. When audiences are engaged with the story, they can better appreciate the aesthetics of Thai dance-drama. Moreover, Laweng was traditionally presented with, to borrow Laura Mulvey's term, through the "male gaze" of both Sunthorn Phu and Phra Aphai Mani (Mulvey 1975). By contrast, our new script focuses on Laweng and her motivations and goals, permitting viewers to see their development, which have not been told in any version of Phra Aphai Mani. The perspective in the script offers a fresh opportunity to examine this well-known romantic scene. Audiences familiar with Lakhon Phanthang and Phra Aphai Mani will be able to see Laweng's actions in a new light.

\section{The Theatrical Production and Design of Leh Laweng}

Staging the new script in a post-traditional style was both challenging and rewarding. Since we sought to stage it with new theatrical techniques and ideas of performance, we experimented with various concepts and working processes not used in traditional Lakhon Phanthang. Our working process differed from those typical for in the genre, and reversed the normal production process from that used in Thai traditional drama, which starts from selecting a script and then arranging the songs for the whole play before picking performers. We first chose Nang Laweng, the beautiful European queen character from the story of Phra Aphai Mani, as the main character, then did the casting, devised the plot, wrote a new script and only then arranged music and songs for the production. This process permitted performers to be directly involved in the production process from the beginning to the end. Performers had more roles, since they are crucial to the production, not only as actors, but also as those best able to provide insights on how to convey meanings to the audiences. Their abilities, opinions and suggestions are valuable to help us make a successful production. We wanted the performers to step out of the comfort zones of traditional performance training and process, to use their traditional 
skills to explore the unfamiliar world of modern theatre with, and this required sustained work with them. Leh Laweng-Lakhon Phanthang was thus created in a post-tradition style to stimulate the performers to extend their capabilities beyond their familiarity and their training. This helped them expand their dramatic performance abilities and gave the production a more post-traditional look and feel for both performers and for audiences.

\subsection{Casting}

Many Thai traditional dramas were staged from 1947 to 1967 by Mr. Dhanit Yupho, the director of Fine Arts Department, including those in the Lakhon Phanthang form. Characters cast in Lakhon Phanthang pieces for much of that time were normally performed by women, regardless of the gender of their roles. For example, Ms. Suwannee Chalanukhroa, a national artist, played the male lead in Phra Lor (1948) and Krai Thong (1949). In 1952, Phra Aphai Mani was restaged and performers were cast according to their gender identities (Yupho 1963, 189-26o). This gender-based casting was used in Lakhon Phanthang performances like Phu Chana Sib Tid, the Myanmar Warrior, directed by Dr. Seree Wangnaitham. It became a conventional, if not a traditional, part of Lakhorn Phanthang, since directors only looked to females to play all roles. Our casting of Leh Laweng focused on the performers' abilities as the key criteria for deciding roles rather than their gender.

Laweng Wanla was the lead character of Leh Laweng. The incidents in the play are narrated and reflected through her thoughts and decisions. Laweng is a lady born in a foreign royal family but who was raised under the protective care of her father and brother, developing warrior skills, making her courageous and shrewd. Laweng was played by a transsexual performer who has trained in Thai traditional dancing since she was ten years old. She was welltrained to play Thai traditional male protagonists in the Faculty of Fine and Applied Arts at Chulalongkorn University. She has specialized in female protagonists since she trained with knowledgeable professors, and been cast as leading female protagonists in numerous Thai traditional dramas. This made her able to play well both as a man and as a woman. In the new plot of Leh Laweng we developed, we presented Phra Aphai Mani through the viewpoint of the female lead character, quite different from traditional Lakhon Phanthang approaches to the story. This focus on a female rather than a male character helps to make it a post-traditional Lakhon Phanthang play. Cohen notes that although "each element of tradition is open to acceptance, modification, or rejection," it is sometimes necessary to step outside of tradition since "tradition not only serves as symbol of continuity, it delineates the legitimate limit 
of creativity and innovation" (Cohen 2016b, xxii). Our casting was modified to serve the needs of the new play, since we did not follow traditional casting practices for Lakhon Phanthang, which is based on gender of the performer. For us, gender was not an obstacle, helping to mark it out as a post-traditional production. Transsexual, male and female performers could take the roles needed in the production, depending on their skills and appropriateness to their role. The researchers chose to cast Laweng without regard to her gender since we wanted Laweng to be able to perform both as a charming woman with feminine charms. Additionally, she could use weapons onstage, and use her battle skills and bravery to mark her out as someone with masculine qualities.

The role of Laweng in our play required a dual gender identity, depending on her action at different points in the production. Although choosing a transsexual to play Laweng was not the first done in Thai traditional dance-drama, we wanted to remind viewers of the importance of gender issues in today's Thai society. Feminine and masculine qualities are diverse and fluid, and do not only dependent on physical appearance. Our transsexual casting in Leh Laweng reflects the current situation of Thai society.

Phra Aphai Mani is a key role in Leh Laweng, although he only appears in the last scene. Our play sees him as a handsome philanderer who always falls for attractive women, full of imagination (or daydreaming) and highly romantic. His specialties are oboe-playing and war. He was born and raised to be a king. The performer who took this role has a strong background knowledge of Yak (Giant role) in Khon (Thai classical masked dance), from Angthong College of Dramatic Arts, so he usually played the giant role. Traditionally, the Phra Aphai Mani character in Lakhon Phanthang is someone well-trained in the male lead character, not one trained in a giant role. Our new Leh Laweng, done in a post-traditional Lakhon Phanthang style, sought performers who challenged themselves and tried something different from their training and skills. The movements used in giant role seemed similar to movements of male protagonists in Thai classical dance, but their limb movements and body balance, including facial expressions, differ. Transforming him from a giant character to male lead character is an interesting challenge. The researchers believed that playing as a male protagonist would challenge the performer. He needed to alter his emotion, dancing postures, and facial expressions in the end of our play for Phra Aphai Mani unlike those of the traditional versions.

The Three Princes from the Three Kingdoms: These three characters are foreign noblemen, but we selected comedians to play them. Their ad-libbed comedic performances appealed to audiences as they offered to help Laweng 
fight Pluek city, hoping to be marry her. Our play turned the graceful and serious images of the foreign princes typical in traditional performances into those of comedic buffoons, we chose three performers with extensive experience in comedian roles in Thai classical masked dance. All trained for more than a decade as Thai classical comedians with Thai classical dance specialists in the Department of Fine Arts, and knew Thai classical dance from the College of Dramatic Arts.

Longka Noblemen: These two shrewd noblemen, who change Laweng's mind, were cast to performers who had been trained to play giant and a male lead roles in Thai classical dance. These tricky characters were adept in convincing Laweng to do what they wanted, but they themselves were cowards. The performers could sing Thai traditional songs and narrate Thai traditional masked drama.

Longka Maids: The two supporting maids who care for Laweng perform roles like the maids of the twin princesses, Phra Pheun and Phra Phang, in the Lakhon Phanthang play Phra Lor. But we use the two maids in Leh Laweng to play new comedy roles in Scene 3, so they needed to be skilled comics and able to move the plot forward. The two female performers come from different backgrounds, but both had long experience in Western style theatre.

As the director, I, Phakamas, selected performers for their abilities and qualities for the various roles of the post-traditional style of our new Leh Laweng play. I chose those with strong backgrounds in Thai classical dance-drama, even though they were often cast in roles for which they had little training. Since we wanted the performers to use modern theatre techniques and ideas of space for the performance, my choices led to some challenges. The performers strong traditional training became the default mode of their onstage movements, and it was challenging to alter this mode. This made it hard to develop a "post-traditional" style of performance for them which would carry the new plot forward. According to work in post-traditional praxis, the director reinvented tradition using some traditional theatre elements. This project attempted to create multidimensional characters in the play who have background and motivation for their own action. The director encouraged the cast to observe themselves and to think about the motivation and background of characters in the new play rather than mimicking the images of the characters typical in traditional Lakhon Phanthang. By applying new ideas and techniques from other theatre styles beyond those of traditional performers, the performers were able to produce a "post-traditional" style beyond their traditional training and principles. 


\subsection{Music and Songs in the Play}

Unlike in traditional performance, we made the music and songs for our new play after the script and casting were completed. I wanted songs to be more interesting and compelling play for today's audiences. I required the Thai classical music ensemble "Phetchkhalai" (Phetchkhalai Band), all professional musicians from the Krom Silapakorn, to do the songs for our play. ${ }^{3}$

A key goal I had as director for working in a post-traditional Lakhon Phanthang style is help traditional performers step out of the limitations imposed by their traditional training. Musicians usually make music and songs for Thai traditional dance-drama, setting the flow of the performance. Other performers work on the dance movement only after the music and songs have been completed. The production concept in our production let the main actors meet and talk with the professional Thai music ensemble. I wanted the performers to be part of the music design, which would help them understand their characters better. I communicated the idea of the production and the concept of music and songs that I wanted to present in the production to the musician ensemble. This music concept consisted of the following:

1. "Ok Phasaa songs" and Thai classical music and songs were used since they were typical in traditional Lakhon Phanthang. But Ok Phasaa songs were used for western characters from Longka and Thai classical songs were used for Thai characters in Pluek city.

2. New verses were inserted between the music used in the drama, including duos.

3. Most songs, especially those with English words, had to be sung clearly to ensure accurate pronunciation and understanding. The Thai classical songs were sung more simply, using less sophisticated singing techniques to make clear the sound of each word.

4. The music and songs had to be played precisely and clearly.

The professional musicians designed the music using these concepts. They then played the new versions live during rehearsals. The actors spontaneously adjusted their singing to suit the performance under my supervision. The new pieces of music were recorded and divided into tracks for the performance, so the actors could rehearse their parts separately and properly as needed. From the rehearsal period up to the dress rehearsal, several changes in the music

3 The music ensemble "Phetchkhalai" (วงเพ็ชรคล้าย) is a private group of professional musicians from the Krom Silapakorn or Department of Fine Arts of the Thai Ministry of Culture. Its members are professional and senior musicians and singers of the Krom Silapakorn. 
required me to refine the music with the musicians and to work with the performers on these changes. The new versions of music and songs emerged through collaborations between the director, actors and professional musicians. They consisted of 23 songs, in three groups.

1. "Ok Phasaa Farang" songs, such as March Damrong, Marching to Georgia, and Queen Damras.

2. Thai classical songs with Western rhythmic beaten by percussion, socalled "Thang Farang" such as Vessukama Thang Farang, Krabong Song Mai Thang Farang

3. Other "Ok Phasaa' songs with Western rhythms and percussion, like "Ground Ram Phama."

Working with professional musicians made it hard to distribute music in the play. But including Thai classical songs in an inventive way created a fresh and fascinating atmosphere. So, the "Rai Farang" song was created for Leh Laweng, sung in a chorus style, giving a different tone. Actors could put their dialogues into songs. Working closely with the Thai classical music masters let us solve problems that arose and extended the songs in the play, giving it a unique sensibility not found in traditional performances.

\subsection{Reading Rehearsals}

Once we had a cast and music for the play, we held reading rehearsals. This relatively new practice for traditional plays excited our Thai traditional drama performers. Although it can be regarded as a western technique, in 1985 Seri Wangnaitham (Director of Fine Arts Department) held a reading rehearsal for the Lakhon Phanthang piece Phu Chana Sib Tid, or The Myanmar Warrior (Jirajarupat 2014b, 417).

In our first reading rehearsal, the actors were puzzled, but excited. Most spoke and interacted with each other in a Thai traditional dramatic style. The actors did the reading rehearsal without interacting with other as actors in a scene. They did not think about the motivation and action of characters, but just read their part of the script. I solved this problem by clarifying the characteristic of each character in the play and allowing all actors to interpret and understand their character. During the second reading rehearsal, the actors were more relaxed and better understood the motivation and intention of characters, and interactions between characters seemed to be based on motivations and actions, and the situation of the play.

The actors had to practice and review their reading rehearsal on their own, treating it like their homework. They designed new ways to speak dialogue clearly, naturally and confidently. It was difficult for traditional performers. Who were familiar with dancing with verse and unfamiliar with a scripted 
dialogue. Despite many reading rehearsals, most of performers worked onstage by falling into performing like what they had been trained.

\section{4 Directing Lakhon Phanthang in a "Post-Traditional Style"}

Lakhon Phanthang is now a fixed form of Thai traditional dance-drama. We sought to open up this fixed form through a new woman-centered script and introducing traditional performers to modern theatre techniques, developing one type of "post-traditional" Lakhon Phanthang. It was challenging to teach the traditional performers modern theatre techniques. Arranging onstage movement in Thai traditional dance-drama is normally done through choreography, since dance is the most important part of the performance. Choreographers design movements of performers, including the concept and direction of the production beforehand. They show the dance movements, and the performers imitate them and the facial expression.

Our post-traditional Lakhon Phanthang style Leh Laweng production differed markedly from this traditional approach. I first explained the objectives and drives of each character, and let the performers act freely according to their designated roles and to sense of their partners onstage. Performers' movements and positioning onstage needed to change, with their facial expressions and dancing postures. I suggested how the performers could improve their skills before the next rehearsals and gave them a concept from the script, and daily life conversation, rhythmic verses, and songs. The more modern plot asked the performers to portray their characters through their acting, for example, asking them to speak naturally is the script showed a daily life dialogue; and to sing while dancing if there were verses in the script.

This kind of acting challenged the actors in Leh Laweng who were trained in Thai traditional dance-drama. Breaking from the manners, conventions, and movements from their traditional training to behave "naturally" onstage was difficult. They automatically performed their assigned roles using their traditional skills. Since they lacked experience in modern acting, they found it difficult to effectively do it.

In directing Leh Laweng, for Scene 1, Laweng rises to the throne after her father, the King, is killed by Phra Aphai Mani. This act took the longest time to rehearse since there were many moments that required Laweng to show her inner drive. She also had to show how she would trick Phra Aphai Mani to take revenge for the death of her father and brother. For Scene 2, where Laweng tricks her suitors to fight with her against Phra Aphai Mani, she meets three princes from other countries who volunteer to fight with Phra Aphai Mani's 
army. Scene 3 shows the maids joking about the weakness of Laweng's suitors in their fights against Phra Aphai Mani, while in Scene 4 Laweng fights Phra Aphai Mani on the battlefield. To direct these four acts, I needed to deal with several items, each of which I will examine below. These include issues tied to performers' physical movements, the energy of their dance movement and poses, their blocking and stage movement, how to make jokes come alive in front of the curtain, showing simultaneous situations onstage, adjusting dance poses, and directing the final battle scene.

The traditionally-trained performers embodied stylistic movements that differed from those in modern drama, so it was difficult for them to move in realistic daily-life situations and to use daily-life dialogue. When no music was being played, the actors walking pace tended to follow the rhythms of their speech from their training. Since traditional protagonists perform at a 45-degree angles, they also usually stood at 45-degree angles rather than looking face-to-face. Performing in a more realistic and lifelike style required these classical performers to "remember" what "natural" behavior was, so they would avoid falling into their default classical dance-drama postures and movements onstage.

Acting "naturally" or realistically was thus unnatural and uncomfortable to them. For our new production, I asked them to confront how they were trained to perform differently. They needed to step outside of their comfort zones and I tried to alter their stage movements. While first letting them play with the script freely while they acted in a traditional dramatic manner, I adjusted their acting by reducing unnecessary movements to just the basics. I next frequently reminded the actors to make their realistic acting align with the script. This helped to step out of their comfort zone and get a sense of what it was to "act naturally."

Lakhon Phanthang centers itself on specific traditional Thai dance poses. Although we kept these poses in our play, we also mixed them with some other dance styles. Some of the script was written in rhythmic verse, so the traditional performers needed to carefully and slowly dance, following the verse word for word. That sometimes meant their poses equaled the number of words in the verse. Our new Leh Laweng production led me to specify that someone playing a character from Longka should move with a mix of Thai dance movement and other dancing styles to show their foreign identity, while those playing someone from Pluek city should dance in just Thai traditional dance poses.

Decreasing the number of dance movements led to a mismatch with the numbers of verses. Each line of verse could include several words grouped 
together, but they would be matched to just a few poses to highlight the key words of the verse. For example,

Through the plot led by her highness Fearlessness, intruding without care Shrewd tricks by a mastermind who bears The portrait for seducing Phra Aphai.

The words in bold of this stanza were used as keywords to mark the dance poses to help performers to better convey their intended meaning.

After the actors used "natural acting" in their performances, I let them try poses they felt would most suit the situation, according to their interpretation. Despite understanding the script and the dance poses, they could not easily make this adjustment, so it was difficult to direct them. When performers chanted, they could not perform naturally and freely, so it was difficult to perform, since they could not coordinate their mental understanding with their bodily movements. I thus provided choreography for them rather than let them create their own dance moves, and they had to imitate and memorize the dance movements I told them to perform. This created new problems, since the performers showed no energy in their performance of these choreographed movements. They tried to mimic the dance I prepared because they felt they needed to mimic every detail accurately, like their training had prepared them to do.

Due to the weak energy in this type choreographed performance, I let the actors use familiar classical dancing patterns of lead performers (both male and female), giant and monkey. They still needed to infuse their dance with new feeling and energy while dancing, and had to adapt this energy into their dancing poses according to their roles.

I first tried to let the actors move around the stage to observe whether they understood their assigned roles or not, but the actors still moved or posed themselves in one way. For instance, they faced the audience and lined up in a single row, even though they were supposed to converse with other characters onstage, since it is customary in Thai classical plays for performers to face the audience all the time, whether they are dancing or talking, so the audience can appreciate their beautiful movements, poses and costumes. To emphasize the motivation and feeling embodied in the action of each character, I had to do more blocking of their movements to different areas on stage to produce the desired authentic feeling and emotion. I encouraged the actors to focus on the character's action rather than to present beautiful dance movements or costumes. So, if the script required two actors to dance and talk to each other, both needed to perform face to face like in daily life. Moreover, blocking and 
stage movements with various levels on stage is important to help reflect the characters' motivation and reasons for their movements. This created an appealing perspective of the play and could attract the audience's attention.

Thai classical theatre has two types of jokes: improvised jokes and scripted jokes. The latter are most common in traditional performances. Performers can choose the topic of jokes themselves with the director's approval. The jokes written for Leh Laweng in Scene 2 and 3 of the script were scripted jokes, but after the actors tried these scripted jokes, the scene seemed too serious and the actors spoke their lines lifelessly. These included scripted jokes among the three princes who came to help Laweng fight with Pluek city, but these jokes were too difficult for them to remember, since the highly experienced actors were more used to doing ad-lib jokes. They saw scripted jokes as unnatural stumbling blocks which slowed down the "live" flow of the play. I let the actors to improvise jokes, which worked well for them. These highly experienced actors were familiar with telling ad-libbed jokes, they performed this part of the play smoothly in a hilarious way that delighted audiences.

In Thai classical dance-drama, male comics normally do comedy in front of stage curtains, since some jokes are dirty and deemed inappropriate for women. Few women actors in Lakhon Phangthang perform jokes in the front of the stage curtains. Our play decided to use two female actors to perform jokes as Laweng's two maids before the show curtains in the third act. Their jokes help to convey the plot, while serving as an intermission show between the two acts so other actors could change their costumes and so the set crew could change the scenery behind the curtains. The jokes for the two female actors were fixed and included humorous lines so the audience could relax while being updated on the plot. The maids mockingly told how the petty jealousies of the foreign suitors who vowed to fight for Laweng led to their deaths, so that she would have to fight Phra Aphai Mani by herself.

Scene 3 with the two maids telling jokes in front of stage curtain was a twosided coin. It could be seen as a long-winded scene which risked tedium, but it was needed to permit Laweng to change costumes and to prepare new props and sets for Scene 4. Thai traditional dance-drama productions with a long story or of many episodes normally include at least two casts, two performers for each character, so they alternate performing in different scenes. But Leh Laweng used only one cast, so the performer playing Laweng had to appear each time she was in the scene. So the jokes in front of the curtain by two maids bridged between Scene 2 and 4 . Since few women perform jokes in Thai traditional dance-drama, this Scene 3 provided them an opportunity to do so, which helped reach one aim of this research; namely, to disregard gender and focus on the actors' abilities. We moved into a post-traditional Lakhon 
Phanthang mode by expanding roles for women, developing a new direction for traditional dance-drama tied to gender in the future.

Thai classical drama normally presents a single main active character onstage, with all other characters staying still or moving little, since classical drama focuses solely on the main character onstage. By contrast, the Leh Laweng "post-traditional" style showed parallel simultaneous situations on two different parts of the stage. This presented relationships between those two situations and concisely presented the main plot. So, Scene 2 and 3 used the stage differently than in traditional performances. As three foreign princes who wanted to volunteer themselves to the battle with Pluek city waited for Laweng on one part of the stage, each improvising traditional dances to show their personalities, Laweng was shown with her maid in another part of the stage while she mimicked the dances of each of the princes for Laweng to show the character of the three princes. Showing to parallel situations onstage through lighting changes is uncommon in Thai traditional drama and gave it a posttraditional sensibility.

Since every actor in Leh Laweng had a strong Thai classical dancing background, we sought to adjust their dancing poses to the new play. The actor who played as Phra Aphai Mani was trained in the giant role, but in this new play, he performed as a male protagonist, so I needed to show him how to move more like a male lead than as a giant. I first let him perform his role independently according to his own understanding. I sought to reduce and simplify his poses and movements, especially the energy of his dance, so he could focus more on his facial expressions. This process stimulated the actors, permitting them return to their primary traditional dance skill and to become familiar with the new script in their comfort zone. It also allowed them to present their actions and the inner world of their characters in their own way based on their backgrounds. As the director, I tried to give them guidance about tuning into their role, and to balance between the actor's skills and production requirements, and to guide them out of their comfort zone. This improved the actor's confidence to act or do something that they were not familiar with, so when they were onstage, they could perform naturally.

The movement and dancing poses of Laweng and Phra Aphai Mani in the final battle scene (Scene 4) had several goals, from keeping their movements simple and brief, to using weapons used to match those used in the traditional play, while showing the shift of the characters' emotions from hate to love, and to shows dances which represented multinational characters.

Scene 4's dance poses were for four people (double-duo dance: two people and two horses), and show battle between Phra Aphai Mani and Laweng while riding their horses. The dance was based on classical dancing poses mixed with 
western dance poses and blended the hand and foot movements and turning movements into Laweng's dance. Actors needed to focus on both their body balance and maintain their energy, since the set required actors to dance powerfully and gracefully.

In directing Leh Laweng, I sought to create a piece to highlight the strengths of those trained in traditional hybrid Lakhon Phanthang music and dance, while using performers cast in unfamiliar roles. These were modified with some elements of modern performance such as blocking and new movement in a new stage space. It required much ad hoc experimentation and evolving processes of communication during rehearsals. It was sometimes difficult to communicate new modes of performing to the dancers, comedians, and musicians in rehearsals, but it made me realize the importance of listening to performers and adjusting the script. Directing also required sometimes simpler, more concrete, options for traditional performers so they could better explore new styles or modes of performing unfamiliar to them, or seek new ways to use stage space and lighting. Since they had never worked in a new mode of performing, this type of experimentation, it opened the door to future work in this area.

\section{5}

\section{Conclusion}

This article examined the creative process the authors used to reinvent a posttraditional Lakhon Phanthang hybrid theatre play for $2 \mathrm{~s}^{\text {st }}$ century audiences in Bangkok. The new play, called Leh Laweng or "The Wiles of Laweng," turned the traditional the Lakhon Phanthang story upside down to examine how and why the often neglected foreign woman character Laweng came to fight one of the key protagonists in this tradition, Phra Aphai Mani. The evolving set of experimental techniques used in the staging of this woman-centered story likewise disrupted traditional approaches to performing. Besides putting traditionallytrained performers in non-traditional roles based on their performance abilities more than their gender, and then developing new types of music and songs for them, we also asked them to include some modern drama techniques into their performance, sometimes in unfamiliar stage environments. The resulting play and performance sought to develop better ways to rework old performance traditions, to expand the roles for traditional actors, and to better communicate with contemporary Thai audiences in a post-traditional style.

Leh Laweng is just one example of how one could work with Thai traditional dance-drama in contemporary society. Creating Leh Laweng explored how 
traditional performing arts values could be reworked to become part of more appealing performances for today's audiences. The production aimed to reinvent a tradition by making Lakhon Phanthang in a post-traditional style. Traditional Lakhon Phanthang served as the benchmark to assess its difference from the new version. "Post-traditional" does not abandon tradition, but seeks to discover how traditions can be reinvented and recycled for a new world, while still keeping key aspects of the tradition alive. This article demonstrated that the processes used to create Leh Laweng were one type of doing post-traditional Thai dance-drama.

Audience feedback was quite positive and encouraging. One young audience member said that before she saw this show, she did not know about Lakhon Phanthang and Phra Aphai Mani, but that afterward she wanted to study more about her, so would find Phra Aphai Mani stories. Comments from Thai traditional theatre scholars and professional performers who were familiar and had strong background in training with Thai traditional dance-drama noted how this production was new, exciting, and enjoyable. It differed from traditional Lakhon Phanthang performed by the Krom Sipakorn, but it still contained key elements of traditional Lakhon Phanthang. Some scholars familiar with western theatre area noted that there was no clear climax in this story, that the acting of the characters was not centered on their motivation, and stressed that the tricks of Laweng seemed weak (Jirajarupat 2019, 325). The feedback and comments showed that the appreciation of theatrical production is open to many interpretations and included subjective views which depended on the experiences and background of each viewer. This research aimed to reinvent traditional performance into a post-traditional Lakhon Phanthang style and to make this hybrid dance-drama communicate with today's diverse audiences. In these terms, Leh Laweng as a research project fulfilled its goals.

By seeking to reinvent old theatre, we found that the traditional movements and values of the performers was a double-edged sword. Their training and experience helped performers - all highly efficient in the performing arts like singing, dancing and acting - contribute to a new style of dramatic performance, even though follow the director's ideas often took time to include in the performance. Yet, on the other hand, their embodied traditional dramatic skills sometimes conflicted with experimental efforts, by preventing them from stepping out from their comfort zones. Improving the process of creating post-traditional performances may require new exercises or workshops that permit those with knowledge of modern performance to better work with traditional performers. This collaborative process would develop better ways to 
include modern and experimental techniques in traditional performances. Future work in post-traditional performance would benefit from this type of collaborative intercultural working process.

\section{References}

Cohen, Matthew Isaac. 2016a. "Global Modernities and Post-Traditional Shadow Puppetry in Contemporary Southeast Asia" Third Text 30, nos. 3-4: 188-206.

Cohen, Matthew Isaac. 2016b. Inventing the Performing Arts: Modernity and Tradition in Colonial Indonesia. Honolulu: University of Hawaii Press.

Eisenstadt, S. N. 1973. "Post-Traditional Societies and the Continuity and Reconstruction of Tradition." Daedalus 102, no. 1: 1-27.

Giddens, Anthony. 1994. "Living in a Post-Traditional Society." In Reflexive Modernization Politics, Tradition and Aesthetics in the Modern Social Order, edited by Ulrich Beck, Anthony Giddens, and Scott Lash, $5^{6}-109$. Cambridge: Polity Press.

Hinvimarn, Somsuk. 2001. "Thai Women and Leisure Time." In Women Studies 2, The National Commission on Women's Affairs. Office of the Permanent Secretary. Bangkok: Aroon Printing (In Thai).

Hobsbawm, Eric, and Terence Ranger, eds. 1983. The Invention of Tradition. Cambridge: Cambridge University Press.

Jirajarupat, Phakamas. 2014a. "Lakhon Phanthang: Thai Traditional Theatre in the Modern World." PhD Thesis, Royal Holloway University of London, Department of Drama Theatre and Dance, London, UK. Retrieved July 17, 2019, from https://pure .royalholloway.ac.uk/portal/files/23651954/2014jirajarupatpphd.pdf.

Jirajarupat, Phakamas. 2014b. "Seri Wangnaitham's "Phuchanasibtid” and the Modernization of Thai Traditional Theatre." Asian Theatre Journal 31, no 2: 417-38.

Jirajarupat, Phakamas. 2019. "Leh Laweng: The Making of Post-Traditional Lakhon Phanthang." In Phennomenology of Performance, edited by Pornrat Dhamrung, et al., 280-333. Bangkok: Phappim. (In Thai).

Mulvey, Laura. 1975. "Visual Pleasure and Narrative Cinema". Screen 16, no. 3: 6-18.

Polachan, Wankwan. 2020. "Authenticity and Contemporary Musical Theatre in Thailand." In Performing Southeast Asia: Performance, Politics and the Contemporary, edited by Marcus Cheng Chye Tan and Charlene Rajendran, 221-46. Cham: Palgrave Macmillan.

Yupho, Dhanit. 1963. The Khon and Lakon. Bangkok: The Department of Fine Arts. Wongthes, Sujit. 2016. Phra Aphai Mani Make Love, Not War: Anti-Colonial Literature. Retrieved May 20, 2019, from https://www.matichon.co.th/columnists/news_185495. (In Thai). 